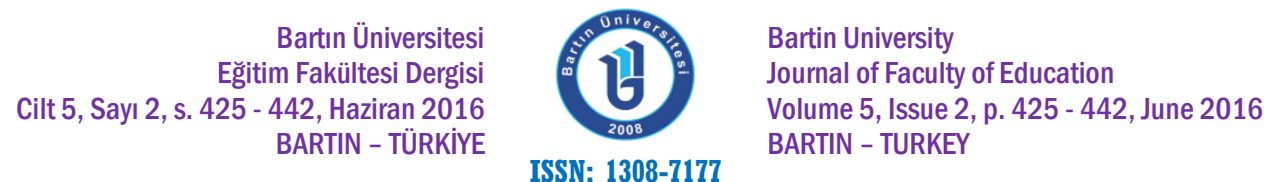

Doi: 10.14686/ buefad.v5i2.5000145998

\title{
Use of Socioscientific Contexts for Promoting Student Agency in Environmental Science Classrooms*
}

Engin KARAHAN, Assistant Professor, Eskişehir Osmangazi University Faculty of Education, karahan@umn.edu Gillian ROEHRIG, Professor, University of Minnesota College of Education and Human Development, roehr013@umn.edu

\begin{abstract}
This study investigated how a socioscientific issues (SSI) based environmental science class can be structured for promoting the agency of the students. This study utilizes the definition of agency that is purposeful actions taken by a student in their own interest or the power of the individual to choose what happens next. Using a qualitative approach, this study employed a descriptive type of case study research design. 31 high school students and a science and a social studies teacher coteaching an environmental science class were the participants. The data collected in this study included classroom observations, semi-structured interviews, and informal conversations with the participant teachers and students in the classroom environment. The data analysis were done through open coding and thematic analysis respectively. The findings of this study indicated that teachers used the multifaceted and interdisciplinary nature of the socioscientific issue to empower their students to select their path based on their personal interests. As a result, the students were more motivated and encouraged to make differences in the society they lived in by using the community-based projects for improving the quality of the environment surrounding them.
\end{abstract}

Key Words: student agency, socioscientific issues, environmental science

\section{Sosyobilimsel Bağlamların Çevre Eğitiminde Öğrenci Failliğinin Desteklenmesinde Kullanılması}

Öz: Bu çalışma sosyobilimsel odaklı bir çevre bilimi dersinin öğrencilerin failliğinin arttırılması hedeflenerek yapılandırımasını incelemektedir. Öğrenci failliği (eylemliliği) bu çalışma kapsamında öğrencilerin ilgileri doğrultusunda bilinçli eylemler gerçekleştirmesi ya da bireylerin bir sonraki aşamada ne olacağını seçme yetisi olarak tanımlanmıştır. Çalışmanın katııımclarını 31 lise öğrencisi ve çevre bilimi dersini birlikte öğreten bir fen bilgisi ve bir sosyal bilgiler öğretmeni oluşturmaktadır. İ̧̧ içe geçmiş tek durum deseninin kullanıldığı bu çalışmada toplanan veriler sınıf-içi gözlemler, yarı-yapılandırılmış görüşmeler ve katılımcı öğretmen ve öğrencilerle sınıf ortamında gerçekleşen doğal konuşmalardan oluşmaktadır. Nitel verilerin analizi ise sırasıyla açık kodlama ve içerik analizi yöntemleriyle gerçekleştirilmiştir. Bu çalışmanın bulguları öğretmenlerin sosyobilimsel konuların çok yönlü ve disiplinlerarası doğasını kullanarak öğrencilerini, kişisel ilgilerine göre seçtikleri yollarda ilerlemeleri noktasında cesaretlendirdiklerini göstermektedir. Bunun sonucunda öğrencilerin çevre kalitesini arttırmayı hedefleyen projeler yoluyla yaşadıkları toplumda fark yaratmak noktasında daha motive ve cesaretli oldukları görülmüştür.

Anahtar Kelimeler: öğrenci failliği, sosyobilimsel konular, çevre bilimi

* This study is part of a doctoral dissertation. 


\section{INTRODUCTION}

Science, in formal school environments, has usually been described as authoritative, monolithic, fixed, and finished (Fensham, 1997; Yager, 1992). Ravetz (2002) criticized this portrayal as follows: "The teaching style [in science education] is dogmatic...students absorb the lesson that every real scientific problem has only one simple, correct answer. This mindset can be seriously disabling for all who eventually deal with science-related policy problems" ( $p$. 109). These existing monolithic practices cause science classrooms missing the voice of students (Pruyn, 1999). The integration of socioscientific issues (SSI) in science classrooms provides a unique opportunity for teaching students the democratic nature of science because it can help students recognize its tentative and organic nature, as well as being "a way of knowing that has freed us from the shackles of received wisdom" (Osborne et al., 2012, p. 4). Also, because they are based on real world contexts, socioscientific issues has potential to connect science in real world contexts and students' lived experiences (Zeidler, Sadler, Simmons, \& Howes, 2005), thus giving students power to make choices and act on these choices in a way that makes a difference in their lives, as well as the environment surrounding them, which Martin (2004) called as agency. In this study, we described how an SSI-based science class can be structured to promote agency of the students. Presenting an SSI-based environmental science class from the perspectives of the classroom teachers and their students, the potential contributions from this study can help researchers and teachers explore different strategies to promote student agency in science classrooms.

\section{LITERATURE REVIEW}

\subsection{Socioscientific Issues}

Reforms in science education have long been to focus not only developing future scientists needed by society, but also educating citizens on scientific progressions (DeBoer, 2000), which has been called scientific literacy since 1950s. Negotiating socioscientific issues is an important aspect of scientific literacy, one of the main goals of science education, and this aspect involves understanding the scientific content related to a social issue, processing information regarding the issue, considering moral and ethical values, and developing a position on the issue (Sadler, Chambers, \& Zeidler, 2004). Socioscientific issues are described as controversial social problems with conceptual and/or procedural links to science (Sadler, 2009; Zeidler, Walker, Ackett, \& Simmons, 2002). Therefore, these problems are affected by different social factors such as politics, economics, and ethics, as well as scientific and technological progressions. These complex and ill-structured problems "do not have single correct answers, cannot be meaningfully addressed through memorized or well-rehearsed responses and are not subject to relatively simple algorithms" (Sadler, 2009, p. 11). Those issues serve as a pedagogical strategy to promote students' awareness of the interdependence between science and society (Zeidler et al., 2005).

Addressing socioscientific issues has been one of the main focuses in science education since the Science, Technology, and Society (STS) movement in the 1970s (Levinson, 2006). Levinson (2008) reported that socioscientific issues drive much of the content in science courses around the world. He added that "prominent reasons given for the inclusion of such [socio-scientific] issues tend to link them to scientific literacy, to focus on the need for scientific knowledge, to help in decision-making and to sustain democracy" (p. 856). Socioscientific issues have been considered an important curricular approach for democratic citizenship through science education because of their potential for bridging school science and students' lived experiences (Kolsto, 2001; Zeidler, Sadler, Simmons, \& Howes, 2005). The literature has highlighted SSI approaches for an essential reform to science curricula, focusing 
on controversial and socially relevant issues (Davies, 2004; Hodson, 2003; Kolsto, 2001; Lee \& Witz, 2009; Levinson, 2006; Ratcliffe \& Grace, 2003; Sadler, Barab, \& Scott, 2007; Zeidler, 2003). However, the literature indicates that research in SSI-based interventions is relatively new (Sadler, 2004; Zeidler, Sadler, Applebaum, \& Callahan, 2009), and there is a need for understanding more about the effects of SSI-based learning environments (Sadler, 2004). Despite the growing body of literature in SSI, only a few researchers have gathered empirical data on the effects of SSI-based learning environments (Schalk, 2009).

\subsection{Student Agency}

Despite the fact that school is proposed as the preparation for life, students are mostly expected to conform to normative standards in formal school environments (Basu \& Barton, 2010). In traditional classrooms, teachers hold power on students and constrain students' freedom of action and choices (Foucault, 1982). Similarly, Gilbert and Yerrick (2001) noted that students are being expected to be the consumers of knowledge through memorizing teacherselected facts in traditional science classrooms. Freire (1970) called it the banking concept of education, in which students are only allowed to extend their actions as far as receiving, filing, and storing the deposits. He added that "the educator's role [in banking education] is to regulate the way the world enters into the students ... [and] since learners 'receive' the world as passive entities, education should make them more passive still, and adapts them to the world" (p. 57).

In response to this problem, based on Freire's (1970) ideas Basu, Barton, and Tan (2011) proposed an education model that is "a process of developing a critical consciousness with respect to context, with the power to transform reality, positioning the learner as a growing member of a community, with expanding roles and responsibilities" (p. 355). The experiences of most students in educational settings center around passive, technical, and apolitical actions instead of active, critical, and politicized life-long learning opportunities (Kyle, 1996). Considering the amount of time young people spend in the school environment, this environment has to be an important space that they can shape into the ways about which they care (Basu \& Barton, 2010).

Agency is a term proposed to address the problems listed in the previous paragraphs. It is generally defined as purposeful actions taken by a student in their own interest (Pruyn, 1999; Podolefsky, Rehn, \& Perkins, 2013) or the power of the individual to choose what happens next (Lindgren \& McDaniel, 2012). According to Martin (2004), agency is "the capability of individual human beings to make choices and act on these choices in a way that makes a difference in their lives" (p. 135). Agency requires individuals or group of individuals to take purposeful actions against hegemonic practices, such as actions directed against any given society's cultural and political normative practices (Pruyn, 1999). These individuals upon, modify, and give significance to the world in purposeful ways, with the aim of creating, impacting and/or transforming themselves and/or the conditions of their lives (Holland, 1998). Therefore, examining their identities because this process naturally involves reflection and awareness (Basu, Barton, \& Tan, 2011).

\section{METHODOLOGY}

The purpose of this study is to understand and describe how an SSI-based environmental science class co-structured by a science and a social studies teacher provides opportunities for promoting student agency. This study utilizes the definition of agency that is purposeful actions taken by a student in their own interest (Pruyn, 1999) or the power of the individual to choose what happens next (Podolefsky, Rehn, \& Perkins, 2013). Specifically, the following research question was addressed in this study: 
- How can an SSI-based environmental science class be structured to promote the agency of students?

\subsection{Research Method}

Using a qualitative approach, this study employed a case study research design in order to investigate the phenomenon (student agency) that occurs within authentic contexts (secondary school environmental science classrooms), especially when the boundaries between phenomenon and context are unclear (Yin, 2003). Using a descriptive type of case study (Yin, 2003), this study aims at describing a phenomenon and the real-life context in which it occurred. Among three types of case studies (Yin, 2003), the case study design implemented for this study is considered a single case having embedded units (see Figure 1), which allows the researcher to look at the same issue (student agency in secondary school environmental science classrooms), but to be intrigued by the different decisions made by participants (teachers and students).

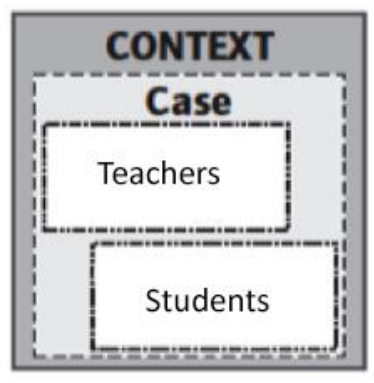

Figure 1. Single case with embedded units (Yin, 2003)

\subsection{Participants}

This study took place during the spring semester of the 2013-2014 school year in a secondary science environmental science class in a school located in a large watershed in the Midwest, USA. The school site is located in a large suburb. Having a rapid growth in population in the last ten years, the city has experienced sprawling commercial and industrial development, as well as a very changed residential demographic from just a generation ago. The student population in the district consisted of $65.3 \%$ Caucasian, $13.4 \%$ Asian, $12.1 \%$ Hispanic/Latino, 7.3\% Black/African American, and 1.9\% American Indian. The class is cotaught by a science and a social studies teacher who participated in a professional development program that focuses on environmental sustainability issues around a watershed. There were 31 students ( 25 boys and 6 girls) taking the environmental science class.

\subsection{Data Collection}

The data collected in this study included classroom observations, semi-structured interviews, and informal conversations with the participant teachers and students in the classroom environment. In order to understand and experience the reality as the participants do (Marshall \& Rossman, 1995), the researcher took a participant observer role in this study. Being present in everyday settings, participant observatory methods enhanced the awareness of the researcher about the interactions taking place in the real life context (Glesne, 1999) and made the researcher's presence in the site less obtrusive while understanding the participants' views of their own world (Malinowski, 1961). Being a participant observer also allowed the researcher to build a trust with the participants and to have informal conversations with them to use these dialogues in the study. In addition to observations, the researcher conducted 
semi-structured interviews, as well as spontaneous conversations recorded in the classroom, with both the teachers and six students to understand their views and experiences throughout the academic year.

\subsection{Data Analysis}

Using a selective reading approach (van Manen, 1990), the data was read several times in order to decide the statements or phrases particularly essential or revealing about the phenomenon being described. The thematic analysis of the qualitative data was done via NVivo 10 qualitative analysis software. Miles and Huberman (1994)'s general analysis framework, which includes the steps of data reduction, data display, conclusion drawing, and verification, was employed. By using this approach, rich descriptions that captured the essence of the phenomenon in question from substantial raw data sources were elicited. Using an open coding approach, the patterns were emerged, which lead researcher to build themes.

\section{FINDINGS}

\subsection{The Structure of the Environmental Science Class}

This study took place in an environmental science class which is co-taught by a science teacher and a social studies teacher. The physical space of the class was the Environmental Learning Center (ELC) building located outside of the school building. Thus, the nature of the class was different than most classes which take place in formal school environments. The ELC building is surrounded by the area where different projects of the former students are located. For instance, the botanic garden next to the building was one group of the former students' projects. The physical environment of the class gave students the message that it was different than most classes students experience in the formal school environment. Due to the reasons mentioned above, environmental science was a quite popular elective class in the school, and students take this class for certain reasons, such as its project based and student driven structure. As one student stated,

It is just really like I took the class because I wanted to get out in the environment more. And, that's exactly what we did in the class. The teachers did not hold our hands through like most teachers do. So, we gotta just go off on our own and learn about something we actually cared about. \#Student 4

The main objective of the class is to help students build awareness about the socioscientific issues around their community and take the necessary actions to prevent those issues. The fact that the class is co-taught by a science teacher and a social studies teacher gives students unique opportunities to understand those issues with a unique perspective. Socioscientific issues, which the class mainly focuses on, are necessarily influenced by science concepts and theories, as well as social factors, such as political, economic, humanistic and ethical aspects. However, many science curriculum and textbooks miss those points dealing with social perspectives. While describing how environmental science classes miss the opportunity to present the topics using different lenses, Eddie showed me a page on the environmental science textbook and said:

Look. This is our environmental science textbook we were supposed to follow. This is the only page talking about the policy, economical, and social aspects of the environmental topics. This freaking hundreds of pages textbook only have one figure to show that. \#Eddie

That was one of the reasons they decided not to use textbooks in the class. Instead, they provided videos and articles at the beginning of the academic year as a springboard to increase student awareness about the environmental issues in their community. The first part 
of the academic year was dedicated to extending students' understanding of those issues via use of media and articles, especially if the issues are not apparent in their own context. In addition, students did research about those socioscientific issues outside of the class, and brought the information back to the classroom in order to share with others. As demonstrated by both Kurt and one of his students,

To me I kind of think the starting point is a springboard to understand ultimately, water is the key player almost everything. That concept of grasping the importance of water is hard for kids, especially in this state, in MN because it is everywhere, right? \#Kurt

We kind of learned about in a lot of different ways but we haven't like provided anything from the book. We have seen couple videos and like articles and we all seem to know pretty decent amount about it, but no like specific chapter we learned it through our peers and then like outside sources. \#Student 6

After introducing the basic understanding of environmental topics to students, they mainly focused on two sequential different projects. The first project was called the Minnesota based project for which students were asked to find an issue in Minnesota, to collect information from the people directly involved in the issue, and to share it with the public in different media formats. Some of the topics covered in these projects were the wolf population in Minnesota, composting sites, overfishing, impacts of hormone pills getting in the water streams on fish reproduction, and farm run-off in the river.

Following this project, students started another one that required them to actually go out and fix things. Students took actions to prevent an environmental problem in their community. The overall goal of the second projects was to challenge students to create solutions for their communities, as stated in the quote below.

The first project is just finding information and sharing it with others, this one is actually going out and doing something about it rather than just learning about it. It was a challenge for us to produce something. \#Student 2

Some of the actions taken for these projects included collecting the information about the problem, finding connections to reach experts, getting the necessary permissions from the city, doing the project, and presenting it to the public at the end of the school year. These projects included building a rain garden, designing loon nests on lakes and ponds, educating younger kids about bees, and installing filter strips to prevent nitrates from entering rivers (See the Figure 2).

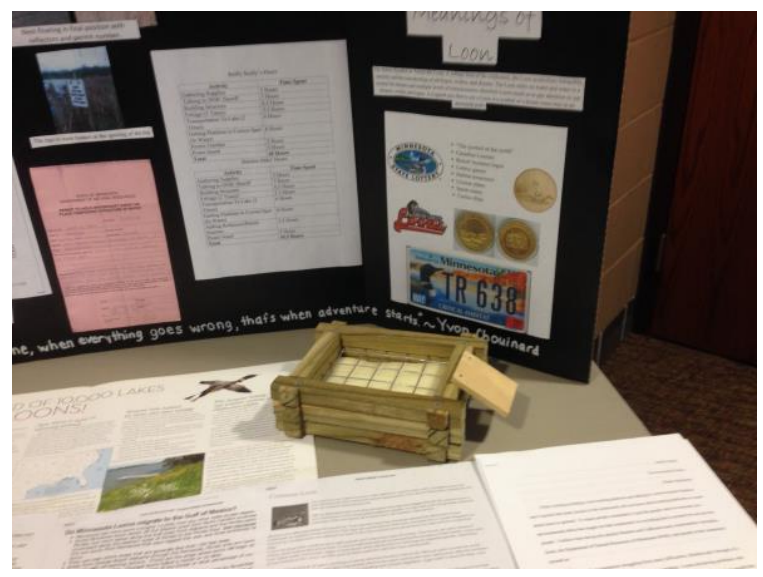

Figure 2. Loon Nesting Project 
When Eddie and Kurt described the way they would like to structure the class, they stated that their goal was to look at the environmental community problems with diverse perspectives; thus, students would be able to make connections easier regardless of their interests and backgrounds. They also highlighted that it provided more opportunities for students to explore their interests since the class was structured differently than most science classes that only focus on scientific aspects. By introducing community-based environmental issues with more than one perspective, they believed that students could feel more connected by choosing the lens to which they felt closer. The following quote illustrated their perspectives with regard to addressing different student interests.

I think the structure and framework of this class lens to find that interest a little more. We want them [students] to find out what they are really interested, what they really care about. And, that's the need thing about what we can do. \#Eddie

At large, the class was structured in order to create the opportunities for students to have more responsibilities in their own learning progression and actions. In the following section, we will present Eddie and Kurt's strategies to create a space for agency in their classroom as well as their motivation for it.

\subsection{Strategies for Promoting Student Agency}

During the academic year, Kurt and Eddie frequently highlighted their faith in student agency. They stated that it is their responsibility to create a space for student agency in their classroom, and student agency is vital in order to appeal to students with different backgrounds and interests. While describing their views about agency in their classroom, their views fell under three main themes: recognizing different levels of student interests, designing a student-driven class, and figuring out students' interests.

\subsubsection{Recognizing Different Levels of Student Interests}

Although some believe that students in the same age group have the same level of interests, motivation, and preferences of content, that is usually not the case. It has always been challenging to address a variety of different interests individuals have in classrooms. That is why educators usually opt for ignoring those differences and approaching all students as one individual. On the other hand, Kurt and Eddie recognized the variety in their students' vested interests, and actually appreciated those interests, instead of ignoring them. They frequently stated that it was the way they kept all students invested in the learning process. They tried to present the class content as broadly as possible to cover different vested interests. In addition, in case some students did not buy the content as it was presented, both teachers were open to different approaches that students could choose The quote below shows how teachers structured the class to encourage their students choose the piece they felt passionate about.

It is actually kind of what I like the class because there is a few kids that actually see that as a big issue. But, others are kind of investing and have a different, and that's fine. They have a different investment in our vested interest or something else. Maybe that's not, they don't see that connection right away. I like that kids kind of get to choose which way they wanna go in this class. So, this is the big part for some of the kids, but I don't think it is a deep part for all the kids' understanding. \#Kurt

In addition to the teachers' own efforts, the SSI focused content also helped them to give students opportunities to find their interests. Like most socioscientific issue based content, the issues around the Minnesota River Basin are both multifaceted and they are the interest of different groups of people with a variety of different perspectives. Therefore, it creates a very wide space for students to focus on what they are interested in within their 
projects. As illustrated in the quote below, Kurt believed that as long as they stayed in the big picture of watershed, students could not only focus on different environmental issues around the river basin, but they could also employ the perspectives of the actors in those issues that they felt passionate about. Hence, the content itself became one of the factors motivating students in the class. In the following quote, Kurt explained how different interests of the students could be connected to the big idea as follows:

I don't think most kids really care about the river basin, or the issue. They don't buy it. But, if they wanna focus on something else that they care about, let's do it. Let's get kids find more about that. Then, connect it to the big idea, the issue around the watershed. \#Kurt

\subsubsection{Designing a Student Driven Class}

One of the most significant and obvious strategies Kurt and Eddie used in their class was giving students power to decide what and how they wanted to learn. They both strongly believed that if students took responsibility for their own learning processes, they could gain expertise on the topics they focused on because of their active involvement in each step. Therefore, they encouraged their students to go on the path that they chose throughout the process. Students were free to decide what they wanted to learn, the way they wanted to learn, the experts whom they wanted to contact, and the media they chose to use presenting their work, as long as they were able to stay in the big picture of the Minnesota River Basin. As shown below, they considered that the best teaching strategy was to give the students control on their own learning.

The best teaching strategy is not teaching them. If kids really want to learn about it, they have to do it themselves. Go out, do research, be an expert, bring it back to the classroom to teach your friends. They are gonna learn a lot about the issue. They are gonna be experts. Eventually, they are gonna have a great understanding about what's going on. \#Kurt

However, it is not easy to provide students the best conditions to take control on their projects, especially if students are asked to present their work at the end of the school year. Regardless of what they believed, the teachers were aware that it was a risk to give teenagers control of the work they did throughout the semester. When Eddie was talking about their plans at the beginning of the semester, he shared his concerns about giving students too much freedom for their projects, as stated below:

Because we gotta have to do something at the end. We look bad too, oh, half of your class showed up with their final project. And, we haven't had that luck you know, but that's my ultimate fear. It is a nightmare for me, cold sweats. \#Eddie

On the other hand, they had particular approaches to keep students on track while working on their projects. Considering that students spent most of their time working in their communities, the teachers worked hard to find a balance between too much control and leaving them alone. Hence, they decided to consult students on the path they chose to work and to have regular check-ins with students to see where they were at in their projects. They met students both in and after class hours to see their progress in their work.

\subsubsection{Figuring out Students' Interests}

Even though students can be very vocal about their interests, they usually need support to figure out what their interests really are. In educational settings, teachers usually use certain assumptions about the interests and motivation sources for the kids in different age groups. While highlighting the role of agency in their class, Eddie and Kurt frequently 
criticized those assumptions and actions taken based on them. They stated that students are usually told and/or assumed that they have interests on particular topics instead of asking them what they are really interested. They recognized both the complexity of helping students to find out their interests and the ways students are forced to have particular interests in the borders of limited content. Eddie described how hard it was to figure out what students were really interested,

Finding what they are interested. It is hard. It is not just 'hey fill out this little survey'. \#Eddie

In response to all these challenges, they proposed the idea that the only and best way to find out an individual's interest was to talk to him/her. According to the teachers, having informal conversations with students could help them find out what their interests were. Kurt demonstrated how to figure out what students were interested as

Finding out the kids' interests. You just gotta talk to them. Dude, what are you interested? \#Kurt

After presenting the big idea of watershed and the socioscientific issues around it, both teachers started having conversations with the students to help them see how their personal interests fit into the class content. They spent a good amount of time to get to know each student better in order to understand what their interests were and what kind of support they needed.

\subsection{Student Agency in the Environmental Science Class}

Considering the student projects, there was a wide variety of topics on which they focused. Some of them were directly related to the watershed, such as installing filter strips in farmlands and rip-rap against soil erosion on shoreline, whereas there were others more related to animal populations in their community, such as designing loon nesting platforms and brown bat houses. Regardless of their focus, students were able to connect their projects to the direct or indirect impacts on the watershed systems.

After the students were introduced to the big idea of socioscientific issues around the watershed, they immediately started to think about what they could do related to those issues. Throughout this thinking process over the course of the semester, I had several opportunities to have conversations with them in order to understand the factors affecting their decisions. It was obvious that their personal connections, in general, played a more significant role than their academic interests while thinking about how to be involved in those issues around the Minnesota River Basin. Living in a community with close connections to rivers and lakes, most students' projects were revolved around their interests in water activities. For instance, fishing is a big deal for the high school age kids living in this particular community. That is why there were a number of students focused on the issues around fishing and fish population in the watershed. As one student stated

The [name of a local lake] one I chose because I love to fish and obviously fishing is not around as much in Lake I have known for fishing especially [name of a local lake] with walleye, I kind of wanna know why and what has been done to improve to fishing there or what has not been done to help it. \#Student 1

In addition, students' personal connections and memories played a critical role in choosing the issues they wanted to focus on in their projects. They preferred to improve the places where they spent time with their friends and family in their town. Since they experienced the impacts of the issues in those places, they felt more emotionally connected, as well as, having more empathy. While listening to them talking about their work, we were 
able to hear personal stories behind their topics. To illustrate, a couple of the students provided the following statements to describe the personal significance of their projects.

I mean that dock pond to me is like my family went down there a lot during the summer just to see the ducks and kind of hang out down there. So I mean it was a big part just to clean that park up for me. That was pretty cool. \#Student 3

For this loon project, I have a cabin in Canada, and we have loons around it. So, I used to, when I was little, I called the loons and they called back, so I kind of learned like loons and care about them, obviously in Minnesota state. \#Student 2

One of the advantages of agency we frequently heard several times in our conversations was the fact that students were motivated to work hard with no complaints because they were working on the projects that they felt passionate about and that had importance for both their communities and themselves. Learning about the content they really cared about and using this knowledge to create solutions for the environmental problems their communities experience increased their motivation, as well as, their feeling of accomplishment at the end. The following quotes show their motivation and passion about their work.

We put in at least forty hours work to complete our project, which wasn't that hard because we accomplished something important for our community and ourselves. \#Student 5

When we do our project, we get to pick our own project that we are passionate about, and have vested interest in. That kind of hits home and it really makes us want to work hard and learn about different issues we actually care about. \#Student 4

Because this projects are like very hands on, self-driven and hard work, and if you are driven and you are doing something you are actually passionate about, then it is like yeah you have direct control but you learn because you take a big topic and try to learn as much about it as you can. \#Student 6

\subsubsection{The Outcomes of Student Agency}

With regards to the unique structure and objectives of the class, the outcomes of the learning processes students noticed were very different than traditional settings. There were a variety of different ways the students used to describe what they got out of the class, and almost none of them were grade-related. They implicitly criticized the traditional settings and how students in these settings learn the content. Having an active role in the process and doing actual work in real world settings were some of the experiences they thought made this class different than other classes. When one of the students summarized the outcomes of the class after the semester ended, she said that,

I think the biggest thing that we have learned in this class was to understand almost how, as weird as it sounds, how we think about nature and how we can change that mindset to put it to better use, and learning how to go out fix things we really care rather than just like sit around and just talk about it. \#Student 2

In addition to what they learned in the environmental context, some students also highlighted the social skills they acquired as the result of taking full responsibilities in the selfdriven projects. The way that the class was structured allowed them to go outside of the school borders and talk to real people in their community about real issues. Real world problems target real audiences outside of the classroom, and students need social skills in order to be able to communicate with those people. As students stated, they do not really 
acquire those social skills in traditional classrooms. They considered the opportunities like learning how to meet and talk to new people some of the most valuable outcomes of this class. The positions of the people they contacted and eventually collaborated with in their work in their community made them aware that they were actually part of their community and potential actors for solutions. Describing the outcomes of the class, they stated

Really we overall got out of this class is we got to learn how to talk to people and meet new people and get their view of different issues. And, that was really we had never done that in any other class. That was really the big thing for me we got out of this class. ... This is all because this class. \#Student 1

You are kind of on your own try to find connections and doing things on your own. Cause I mean we had to make connections with the city planners who made connections with public works for us, and it was kind of cool to see how if you meet one person, he can help you meet the next guy and get connections. \#Student 4

While having conversation with one of the students, he noted that as a group, their best moments mostly occurred in the real contexts where their work was supported and/or appreciated by the actors of the community issues. Due to the fact that they had the ownership in their projects, the recognition of their work made them feel proud and encouraged. Their accomplishment was not rewarded with only a simple grade, but an appreciation from the people who cared about their work. One of the students described his proud moment as

Best moment or learning experience, I would have to say was this past weekend we finished up our rip rapping and I received an email from the head city planner and actually was retweeted on twitter by the mayor of [name of the town] just like congratulating me and saying awesome job on your project, it really cleaned up the park for the community and everything so. That was pretty cool for me, so I was excited about that. \#Student 3

\section{CONCLUSIONS AND DISCUSSIONS}

The findings of the study revealed that the way the course was structured, based on local socioscientific issues around a local river basin, created opportunities where student agency occurred. The teachers gave students opportunities to focus on the contents they felt passionate about, and then, to do community-based service learning projects on those contents. Because the socioscientific issues are multifaceted, interdisciplinary, and the interest of different groups of people with a variety of different perspectives (Klosterman, Sadler, \& Brown, 2012), they create a space for student agency in science classrooms. This study showed that the SSI-focused content led students to focus a variety of different aspects, and ultimately connect those aspects to the big idea. Throughout the process, they had chances to talk to the experts and the actors of the issues in order to understand those issues from multiple perspectives and to create the best solutions. Hence, student agency in science helped them understand the controversial nature of the SSI and improved their perspective taking skills.

Like most local socioscientific issues, the issues around the Minnesota River Basin were mostly community-based problems, and people in the communities around the Minnesota River, including students, have emotional, economical, and recreational connections. Thus, when the students were involved in those issues, students held intrinsic motivation derived from the emotional and internal commitment. This motivation and commitment of the students resulted with deciding the path they wanted to follow in order to be part of the solution. The literature suggests that personally meaningful and relevant focus around 
socioscientific issues provide students opportunities to be involved in the complex decision making processes (Burek \& Zeidler, 2015). Due to their strong connections to the Minnesota River Basin issues, students actively participated in the decision making processes around those issues, as well as taking pro-environmental actions in a way they decided.

O'Neill and Barton (2005) noted that when students have opportunities to cultivate ownership in science, the sense of agency in science empowers students to use it to make changes in their lives and emboldens them to want to learn more science. The students' statements showed that giving them power to choose the content they want to learn as much as they could. Students frequently stated that the feeling of ownership their teachers provided made them more motivated to learn science content, as well as doing their projects to prevent the issues in their communities from happening. They were also able to see the connection between their freedom of choice in content and their motivation to learn this content that they felt passionate about. Several students reported that they spent their free time in the field for completing their projects that aimed improving the quality of the environment surrounding them, as well as the members of their community.

Agency is related to particular social, political and cultural contexts and the term "agency refers to the socioculturally mediated capacity to act" (Ahearn, 2001, p. 28). Using a socioscientific issue focus in the social and cultural context students were part of, the class increased student agency because students saw themselves as part of this social and cultural context where their interests and passions revolved. In contrast to bigger scale socioscientific issues, students' SSI agency was more apparent in this social and cultural context because they felt part of their community-based issues and their potential solutions, which eventually resulted with ownership. Their capacity to make decisions, take actions, and potentially make a difference led them take more control and responsibility in their work. In conclusion, the use of social, political, and cultural contexts in smaller scales while dealing with socioscientific issues increased students' agency.

Challenging the hegemonic practices is an essential piece in agency (Pruyn, 1999). In this study, the participant teachers and students challenged the traditional educational settings in collaboration. As they stated, there were risks present in the process such as students not completing their work; however, taking appropriate pedagogical strategies, the teachers overcame those risks and challenges. On the other hand, the participant students tried different focuses and working processes based on their self-awareness, background, and interests. Even though their teachers provided them with a wide context, they still challenged the borders of this context and addressed different sub-problems in the context of watershed. Additionally, the beliefs and practices of their communities were challenged by these students in order to make a change. For instance, living in a farm-based community, they criticized the existing farming practices and did their projects in order to prevent the negative impacts of those farmlands on the river. Therefore, students challenged the authority and power in their community by taking actions to change the existing conditions, as suggested by the literature (Freire, 1970; Freire \& Macedo 1987 ;Pruyn, 1999).

Holland (1998) described agency as the acts of individuals upon, modify, and give significance to the world in purposeful ways in order to create, impact and/or transform themselves and/or the conditions of their lives. Similarly, critical science agency is defined as students identifying themselves within science in ways that advance participation in their community by taking actions at both individual and community levels (McNeill \& Vaughn, 2010; Basu et al. 2009). Considering the community involvement of this particular group of students, this missing piece of agency in most practices was present in this educational setting. The more students took control on their own learning processes, the more their community 
involvement increased because they sought the information from the experts in real world settings. As one student shared, contacting one person helped them to contact the next person, and eventually building connections with the members of their communities. At the end, they presented their service learning projects and their built expertise to their communities. Hence, this study showed how increased student agency positively impacts critical science agency.

\subsection{Implications}

When students are invited to voice things they are interested in and the learning experience can be somewhat of a co-learning experience, teachers can guide the students to explore environmental science issues through the contexts of things they care about. This, potentially, could support the development of agency, but at the end of the day the students have to be genuinely interested and authentically invested. In addition to the strategies that teachers used to promote the agency of their students in the SSI-based class, the voice of students about their experiences in the class validated the agency existed in this setting. Therefore, it is important for the researchers to present the experienced phenomena from the perspectives of all actors in the setting, which are teachers and students in this case.

In addressing socioscientific issues in $\mathrm{K}-12$ settings, the associated local communities present an invaluable resource and partner. There are organic collaborative opportunities within the community to be realized for mutual benefit between students and their communities. The bonds between schools and communities in which they are located provide students to communicate with the real actors in socioscientific issues and understand their perspectives. From this research and the associated findings, it is obvious that when students feel comfortable to go beyond the school borders and connect with the members of their communities, they get a broader understanding about socioscientific issues experienced by their communities. However, students are not the only beneficiaries in this scenario. The case in this study provided examples of how students can help preventing community-based environmental problems through service learning projects. When their motivation and efforts are responded by their communities, students are more likely to feel responsibilities and dedicate their time to help their communities.

\section{REFERENCES}

Ahearn, L.M. (2001). Language and Agency. Annual Review of Anthropology, 30, 109-137.

Basu, S. J., \& Barton, A. C. (2010). A Researcher-Student-Teacher Model for Democratic Science Pedagogy: Connections to Community, Shared Authority, and Critical Science Agency. Equity \& Excellence in Education, 43(1), 72-87.

Basu, S. J., Barton, A. C., Clairmont, N., \& Locke, D. (2009). Developing a Framework for Critical Science Agency through Case Study in a Conceptual Physics Context. Cultural Studies of Science Education, 4(2), 345-371.

Basu, S.J, Barton A.C \& Tan E. (2011). Democratic Science Teaching: Building the Expertise to Empower Low-income Minority Youth in Science. Sense Publishers: Netherlands.

Burek, K., \& Zeidler, D. L. (2015). Seeing the Forest for the Trees! Conservation and Activism Through Socioscientific Issues. In EcoJustice, Citizen Science and Youth Activism (pp. 425441). Springer International Publishing.

Davies, I. (2004). Science and Citizenship Education. International Journal of Science Education, 26(14), 1751-1764. 
Fensham, P. (1997). School Science and Its Problems with Scientific Literacy. In R. Levinson \& J. Thomas (Eds.), Science today: Problem or crisis? (pp. 119-136). London, UK: Routledge.

Foucault, M. (1982). The Subject and Power. Critical Inquiry, 8(4), 777-795.

Freire, P. (1970). Pedagogy of the Oppressed. New York: Continuum.

Freire, P., \& Macedo, D. (1987). Literacy: Reading the Word and the World. Massachusetts: Bergin \& Garvey.

Gilbert, A., \& Yerrick, R. (2001). Same School, Separate Worlds: A Sociocultural Study of Identity, Resistance, and Negotiation in a Rural, Lower Track Science Classroom. Journal of Research in Science Teaching, 38, 574-598.

Glesne, C. (1999). Becoming Qualitative Researchers: An Introduction. New York: Longman.

Hodson, D. (2003). Time for Action: Science Education for an Alternative Future. International Journal of Science Education, 25, 645-670.

Holland, D. (1998). Identity and Agency in Cultural Worlds. Cambridge: Harvard University Press.

Klosterman, M. I., \& Sadler, T. D. (2010). Multi-level Assessment of Scientific Content Knowledge Gains Associated with Socioscientific Issues-based Instruction. International Journal of Science Education, 32(8), 1017-1043.

Klosterman, M. L., Sadler, T. D., \& Brown, J. (2012). Science Teachers' Use of Mass Media to Address Socio-scientific and Sustainability Issues. Research in Science Education, 42(1), 51-74.

Kolst $\varnothing$, S. D. (2001). Scientific Literacy for Citizenship: Tools for Dealing with the Science Dimension of Controversial Socioscientific Issues. Science Education, 85, 291-310.

Kyle Jr, W. C. (1996). Editorial: The importance of investing in human resources. Journal of Research in Science Teaching, 33(1), 1-4.

Lee, H., \& Witz, K. G. (2009). Science Teachers' Inspiration for Teaching Socio-scientific Issues: Disconnection with Reform Efforts. International Journal of Science Education, 31(7), 931-960.

Levinson, R. (2006). Towards a Theoretical Framework for Teaching Controversial Socioscientific Issues. International Journal of Science Education, 28(10), 1201-1224.

Levinson, R. (2008). Promoting the Role of the Personal Narrative in Teaching Controversial Socio-scientific Issues. Science \& Education, 17(8), 855-871.

Lindgren, R., \& McDaniel, R. (2012). Transforming Online Learning through Narrative and Student Agency. Educational Technology \& Society, 15(4), 344-355.

Malinowski, B. (1961). Argonauts of the Western Pacific. New York: E. P. Dutton.

Marshall, C., \& Rossman, G. (1995). Designing Qualitative Research (2nd ed.). Thousand Oaks, CA: Sage.

Martin, J. (2004). Self-Regulated Learning, Social Cognitive Theory, and Agency. Educational Psychologist, 39, 135-145.

McNeill, K. L., \& Vaughn, M. H. (2012). Urban High School Students' Critical Science Agency: Conceptual Understandings and Environmental Actions around Climate Change. Research in Science Education, 42(2), 373-399. 
Miles, M. B., \& Huberman, A. M. (1994). Qualitative Data Analysis (2nd ed.). Thousand Oaks, CA: Sage.

O'Neill, T., \& Barton, A. C. (2005). Uncovering Student Ownership in Science Learning: The Making of a Student Created Mini-Documentary. Journal of School Science and Mathematics 105(6), 292-301.

Osborne, J., MacPherson, A., Patterson, A. \& Szu, E. (2012). Introduction. In M. Khine (Ed.), Perspectives On Scientific Argumentation: Theory, Practice and Research (pp. 3-15). Dordrecht, The Netherlands: Springer.

Podolefsky, N. S., Rehn, D., \& Perkins, K. K. (2013). Affordances of Play for Student Agency and Student-Centered Pedagogy. American Institute of Physics Conference Series, 1513, 306309.

Pruyn M. (1999). Discourse Wars in Gotham- West: A Latino Immigrant Urban Tale of Resistance and Agency. Boulder, CO: Westview.

Ratcliffe, M., \& Grace, M. (2003). Science Education for Citizenship. Maidenhead: Open University Press.

Ravetz, J (2002). Memorandum submitted by Dr. Jerry Ravetz, Ev. 109, Appendices to the minutes of evidence taken before the House of Commons Science and Technology Committee, Science Education from 14 to 19, Third Report of Session 2001-02. London, UK: The Stationery Office Ltd.

Sadler, T. D. (2004). Informal Reasoning Regarding Socioscientific Issues: A Critical Review of Research. Journal of Research in Science Teaching, 41, 513-536.

Sadler, T. D. (2009). Situated Learning in Science Education: Socioscientific issues as Contexts for Practice. Studies in Science Education, 45, 1-42.

Sadler, T. D., Barab, S. A., \& Scott, B. (2007). What Do Students Gain by Engaging in Socioscientific Inquiry?. Research in Science Education, 37(4), 371-391.

Sadler, T.D., Chambers, F.W., \& Zeidler, D.L. (2004). Student Conceptualisations of the Nature of Science in Response to a Socioscientific Issue. International Journal of Science Education, 26, 387-409.

Schalk, K. (2009). A Case-Study Of A Socio-Scientific Issues Curricular And Pedagogical Intervention In An Undergraduate Microbiology Course: A Focus On Informal Reasoning. Unpublished Doctoral Dissertation, University of Maryland, MD.

Van Manen, M. (1990). Researching Lived Experience: Human Science for An Action Sensitive Pedagogy. Albany, NY: State University of New York Press.

Yager, R. (1992). Viewpoint: What We Did Not Learn from the 60s about Science Curriculum Reform. Journal of Research in Science Teaching, 29, 905-910.

Yin, R. (2003). Case Study Research: Design and Methods (3rd ed.). Thousand Oak, CA: Sage.

Zeidler, D. L. (Ed.). (2003). The Role of Moral Reasoning on Socioscientific Issues and Discourse in Science Education. Dordrecht: Kluwer Academic Publishers.

Zeidler, D. L., Sadler, T. D., Simmons, M. L., \& Howes, E. V. (2005). Beyond STS: A Researchbased Framework for Socioscientific Issues Education. Science Education, 89(3), 357-377. 
Zeidler, D. L., Sadler, T. D., Applebaum, S., \& Callahan, B. E. (2009). Advancing Reflective Judgment through Socioscientific Issues. Journal of Research in Science Teaching, 46(1), 74-101.

Zohar, A., \& Nemet, F. (2002). Fostering Students' Knowledge and Argumentation Skills through Dilemmas in Human Genetics. Journal of Research in Science Teaching, 39, 3562. 


\section{GENiş ÖZET}

Fen sınıflarında geleneksel yollarla öğretilen bilimin otoriter ve tek sesli olması (Fensham, 1997; Yager, 1992) öğrencilerin bu öğrenme ortamlarında kendilerini ifade etmelerini engellemektedir (Pruyn, 1999). Sosyobilimsel konular sosyal konularla (siyaset, ekonomi, ve etik gibi) kavramsal ya da yöntemsel ilişkiler içeren bilimsel problemler olarak tanımlanmıştır (Sadler, 2009; Zeidler, Walker, Ackett ve Simmons, 2002). Sosyobilimsel konular; bilimin demokratik ve çok yönlü doğasını vurgulaması (Osborne ve diğ., 2012) ve öğrencilerin deneyimlerini bilimsel problemlerle ilişkilendirme (Zeidler, Sadler, Simmons ve Howes, 2005), açısından öğrencilere kendilerini ifade etme imkanı verme potansiyeline sahiptir.

$\mathrm{Bu}$ araştırmada sosyobilimsel odaklı bir çevre bilimi dersinin öğrencilerin failliğinin arttırılması hedeflenerek nasıl yapılandırıldığının betimlenmesi amaçlanmıştır. Öğrenci failliği (eylemliliği) bu çalışma kapsamında öğrencilerin ilgileri doğrultusunda bilinçli eylemler gerçekleştirmesi (Pruyn, 1999; Podolefsky, Rehn ve Perkins, 2013) ya da bireylerin bir sonraki aşamada ne olacağını seçme yetisi olarak tanımlanmıştır (Lindgren ve McDaniel, 2012).

Nitel araştırma metodolojisinin desenlerinden biri olan durum çalışması yöntemiyle gerçekleştirilen bu araştırma Amerika Birleşik Devletleri'nin Orta-batı bölgesinde yer alan sosyoekonomik düzeyi orta düzeyde olan öğrencilerin öğrenim gördüğü bir eyalet okulunda gerçekleştirilmiştir. Araştırmanın çalışma grubunu çevre bilimi dersini birlikte yürüten fen bilimleri ve sosyal bilgiler öğretmeni ile bu öğretmenlerin sınıfında bulunan 31 lise öğrencisi (25 erkek ve 6 kız) oluşturmaktadır. İç içe geçmiş tek durum deseninin kullanıldığı bu çalışmada; araştırmacılar tek bir durumu (çevre bilimi dersinde öğrenci failligi) farklı katılımcıların (öğretmenler ve öğrenciler) perspektifinden incelemişlerdir.

Araştırmanın verileri sınıf-içi gözlemler, yarı-yapılandırılmış görüşmeler ve araştırmacılar ile öğretmen ve öğrencilerle sınıf ortamında gerçekleşen doğal konuşmalar aracılığıyla toplanmıştır. Elde edilen verilerin nitel analizinde Miles ve Huberman'ın (1994) verilerin azaltılması, verilerin görselleştirilmesi, sonuca ulaşım, ve teyit etme olmak üzere dört aşamadan oluşan genel analiz çerçevesi kullanılmıştır. Açık kodlama ve içerik analizi yöntemleriyle gelişen temalar üzerine bulgular yapılandırılmıştır.

$\mathrm{Bu}$ araştırmanın bulguları iki aşama halinde incelenmiştir. İlk aşama da çevre bilimi dersini yapılandıran öğretmenlerin öğrenci failliğini arttırmak için izledikleri stratejiler tanımlanmıştır. Sınıf ortamında hem fen bilimleri hem de sosyal bilgiler öğretmeninin olması bu derste islenen sosyobilimsel konuların çok yönlü ve çoklu disipliner olarak işlenmesine, dolayısıyla farklı ilgi ve motivasyonlara sahip öğrencilere hitap edilebilmesini sağlamıştır. Bunun yanı sıra öğretmenler çevre bilimi dersini öğrenciler kontrolünde gerçekleştirilen iki farklı proje üzerine yapılandırmışlardır. Bu projelerden ilkinde öğrenciler gruplar halinde bulundukları bölgede karşılaştıkları bir sosyobilimsel problem seçerek bu konu hakkında toplumu bilgilendirici medya ürünleri hazırlamışlardır. İkinci projede ise yine bulundukları bölgede etkin bir sosyobilimsel konu seçerek, bu konu ile ilgili topluma hizmet projeleri yürütmüşlerdir. Her iki öğretmen de bu projelerin seçilmesinde ve yürütülmesinde öğrencileri hiçbir şekilde yönlendirmediklerini, sınıftaki rollerinin bilgiyi vermeden ziyade öğrencilere kişisel ilgilerine yönelik projeleri bulmada rehberlik yapmak olduğunu belirtmişlerdir. Son olarak öğretmenler sınıflarında öğrenci failliğini arttırmanın en etkili yolunun öğrencilerin farklı ilgi ve motivasyon seviyelerini tespit etmek ve onlarla diyalog kurarak her birinin ilgi, bilgi, geçmiş deneyim ve motivasyonlarını anlamak olduğunu savunmuşlardır. Öğrencilerle yapılan görüşmeler ise öğrencilerin öğrenme süreçlerinde etkin ve karar verici konumunda olmaları durumunda süreç içerisinde aidiyet, motivasyon, sorumluluk ve başarı gibi duyguları daha güçlü hissettikleri ortaya çekmiştir. Öğrencilerin projelerinde çalıştıkları sosyobilimsel konular kendi yaşantıları ile doğrudan ilişkili konular olmuş, dolayısıyla bu projelerin tamamlanması sonucunda öğrencilerde akademik başarısının çok ötesinde bir başarı hissi meydana gelmiştir. Dolayısıyla öğrenciler çevre bilimi dersi kapsamında yürüttükleri projelerde daha fazla zaman ve efor sarf ettiklerini belirtmişlerdir. Bunun yanı sıra öğrenciler süreç içerisinde edindikleri faillik sayesinde içerisinde yer aldıkları toplumda yer etmiş uygulamalara eleştirel bir bakış açısı getirme yetisine sahip olmuşlar ve bu hegemonik ve baskın uygulamalara topluma hizmet projeleri yoluyla önleyici adımlar atmışlardır. 
Sonuç olarak bu çalışma sosyobilimsel konuların öğrenci failliğini arttırmaya yönelik karakteristik özellikleri bulundurmasının yanı sıra öğrenci failliğinin bulunduğu öğrenme ortamlarının sosyobilimsel konuların hedeflediği kazanımlara ulaşılmasına yardımcı olduğunu da göstermektedir. Boylece Martin'in (2004) altını çizdiği gibi öğrenciler edindikleri failliğin sonucu olarak hem kendi yaşantılarında hem de kendilerini çevreleyen bağlamda fark yaratma yoluna gitmişlerdir.

Araştırmanın bulguları öğretmenlerin öğrenci failliğini arttırmaya yönelik stratejilerini ortaya koyarken, öğrencilerin öğrenme süreci içerisindeki deneyimlerine yönelik ifadeleri öğrenci failliğinin bu ortamda varlığını gösterdiği söylenebilir. Bu durum araştırmacıların araştırılan olguyu farklı katılımcıların deneyimlerinden yola çıkarak betimlemesinin önemini vurgulamaktadır. Sosyobilimsel konulara dayalı çevre bilimi dersinin öğrenci failliğini arttırma amaçlı yapılandırılmasını konu alan bu çalışmada gerek öğretmenlerin bu doğrultuda izledikleri stratejiler gerekse de bu stratejilerin öğrencilerde bulduğu karşılık betimlenmiştir. Araştırmanın bulguları eğitimcilere öğrenci failliğinin arttırılmasının hedeflendiği öğrenme ortamlarının tasarlanmasında etkili olabilecek stratejilerin belirlenmesi noktasında yol gösterici olacaktır. 